\title{
Sample Vial Inserts: A Better Approach for Sampling Heterogeneous Slurry Samples in the SRS Defense Waste Processing Facility
}

by

c. J. Coleman

Westinghouse Savannah River Company

Savannah River Site

Aiken, South Carolina 29808

S. R. Goode

Dept. of Chemistry, USC-Columbia

SC USA

A document prepared for WASTE MANAGEMENT '96 at Tucson from 02/25/96 - 02/29/96.

DOE Contract No. DE-AC09-89SR18035

This paper was prepared in connection with work done under the above contract number with the U.S. Department of Energy. By acceptance of this paper, the publisher and/or recipient acknowledges the U.S. Government's right to retain a nonexclusive, royalty-free license in and to any copyright covering this paper, along with the right to reproduce and to authorize others to reproduce all or part of the copyrighted paper. 


\section{DISCLAMMER}

Portions of this document may be illegible in electronic image products. Images are produced from the best available original document. 


\section{DISCLAIMER}

This report was prepared as an account of work sponsored by an agency of the United States Government. Neither the United States Government nor any agency thereof, nor any of their employees, makes any warranty, express or implied, or assumes any legal liability or responsibility for the accuracy. completeness, or usefulness of any information, apparatus, product, or process disclosed, or represents that its use would not infringe privately owned rights. Reference herein to any specific commercial product, process, or service by trade name, trademark, manufacturer, or otherwise does not necessarily constitute or imply its endorsement, recommendation, or favoring by the United States Government or any agency thereof. The vicws and opinions of authors expressed herein do not necessarily state or reflect those of the United States ${ }^{-}$Government or any agency thereof.

This report has been reproduced directly from the best available copy.$$
\because
$$

Available to DOE and DOE contractors from the Office of Scientific and Technical Information, P. O. Box 62, Oak Ridge, TN 37831; prices available from (615) 576-8401.

Available to the public from the National Technical Information Service. U. S. Deparment of Commerce, 5285 Por Royal Rd., Springfield, VA 22161 
WSRC-MS-95-0349

\title{
Sample Vial Inserts: A Better Approach for Sampling Heterogeneous Slurry Samples in the SRS Defense Waste Processing Facility
}

\section{C.J. Coleman}

Westinghouse Savannah River Company

Savannah River Company

Aiken SC 29808

S.R. Goode

Department of Chemistry

University of South Carolina

Columbia, SC 29802

\author{
A paper proposed for presentation and publication in \\ Waste Management' 96 \\ Tucson, Arizona \\ February, 25-29, 1996
}




\title{
Sample Vial Inserts: A Better Approach for Sampling Heterogeneous Slurry Samples in the SRS Defense Waste Processing Facility
}

\author{
C.J. Coleman \\ Westinghouse Savannah River Company \\ Savannah River Company \\ Aiken SC 29808 \\ S.R. Goode \\ Department of Chemistry \\ University of South Carolina \\ Columbia, SC 29208
}

\begin{abstract}
A convenient and effective new approach for analyzing DWPF samples has been successfully tested at the Savannah River Technology Center (SRTC). The new approach, when implemented, will allow the Defense Waste Processing Facility (DWPF) to operate in a more cost-effective manner by dramatically reducing the time required for crucial process control analyses without sacrificing analytical precision and accuracy. The new approach involves the use of inserts with volumes of $1.5-3 \mathrm{ml}$ placed in the neck of $14 \mathrm{ml}$ sample vials. The inserts have rims that conform to the rim of the vials so that they sit straight and stable in the vial. The DWPF tank sampling system fills the pre-weighed insert rather than the entire vial, so the vial functions only as the insert holder. The shielded cell operator then removes the vial cap and decants the insert containing the sample into a plastic bottle, crucible, etc., for analysis. Inert materials such as Teflon, plastic, and zirconium are used for the insert so it is unnecessary to separate the insert from the sample for most analyses.

The key technical advantage of using inserts to take DWPF samples versus filling sample vials is that it provides a convenient and almost foolproof way of obtaining and handling small volumes of slurry samples in a shielded cell without corrupting the sample. Since the insert allows the entire sample to be analyzed, this approach eliminates the errors inherent with subsampling heterogeneous slurries that comprise DWPF samples. Slurry samples can then be analyzed with confidence. Analysis times are dramatically reduced by eliminating the drying and vitrification steps normally used to produce a homogeneous solid sample. Direct dissolution and elemental analysis of slurry samples are achieved in 8 hours or less compared with 40 hours for analysis of vitrified slurry samples. Comparison of samples taken in inserts versus full vials indicate that the insert does not significantly affect sample composition. Experimental results to date indicate that sample vial inserts
\end{abstract}


are a convenient and effective way to deal with heterogeneous slurries in a shielded cell environment.

\section{Introduction}

The Savannah River Site (SRS) will begin in 1996 to process approximately 35 million gallons of high-level radioactive defense waste into durable borosilicate glass at the Defense Waste Processing Facility (DWPF). SRS currently stores the waste in underground tanks with capacities up to 1.3 million gallons. The caustic waste consists of two fractions: (1) sludges that contain metal hydroxides, actinides, and most of the fission and activation products, and (2) water-soluble alkali metal salts that contain most of the ${ }^{137} \mathrm{Cs}$. The salt fraction is decontaminated by adding sodium tetraphenylborate to precipitate ${ }^{137} \mathrm{Cs}$, along with nonradioactive cesium and potassium present in the salt. The tetraphenylborate salts are hydrolyzed with formic acid to yield benzene and an aqueous fraction that contains the ${ }^{137} \mathrm{Cs}$. After distilling the mixture to remove benzene, the aqueous phase is combined with sludge that has been washed to remove excess aluminum and alkali metal salts. Borosilicate frit is added to the sludge and this mixture heated at $1150^{\circ} \mathrm{C}$ in a joule-heated melter. The molten glass is poured into stainless steel canisters and stored and SRS until a geological repository is selected for final disposal.

Elemental analyses of the sludge-frit mixture (melter feed) are the most important and by far the most time consuming process control measurement in the DWPF. Elemental analyses are used to confirm that process streams have been blended correctly to meet the viscosity and durability requirements of the glass product. The elemental analyses of the sludge in the Sludge Receipt and Adjustment Tank and the melter feed in both the Slurry Mix Evaporator and Melter Feed Tank can take up to 40 hours to perform, whereas the other process control analyses can be completed in 8 hours or less. The time difference in analysis means that up to 3 extra days will be needed to process a batch of sludge that otherwise could be processed in 4 days once the DWPF reaches full production. This analytical delay will reduce DWPF production rates and increase the total cost of vitrifying SRS over the life of the DWPF.

A major reason that elemental analyses take so long for these samples is that special precautions are taken to minimize analytical errors with heterogeneous slurry samples. Errors can be especially serious for the SME and MFT samples. The fast-settling frit particles make it difficult to subsample from sample vials without corrupting the relative amounts of frit and sludge in the sample ${ }^{1}$. The sample preparation scheme used to avoid or minimize these errors consists of combining the contents of $2-14 \mathrm{ml}$ sample vials, rinsing the vials with water to ensure quantitative transfer, drying the slurry to a paste, vitrifying the paste in a platinum crucible, crushing the resulting glass to a fine powder, and finally dissolving the powder with 2 different methods for elemental analysis by inductively coupled plasma-atomic emission spectroscopy. When performed remotely using manipulators, the time required to execute a set of 4 replicate analyses can easily take 40 hours of tedious work. 
An analytical scheme has been successfully tested at SRTC that shows promise to produce reliable elemental analyses of sludge and melter feed samples in a fraction of the time now required. The centerpiece of the scheme is to take essentially all DWPF samples with sample vial inserts instead of filling the entire vial so that the entire sample can be analyzed intact without corrupting the sample. The development of the vial insert concept and tests with simulated DWPF melter feed samples are discussed in this paper.

\section{Experimental}

Four different insert materials were used in various applications. Teflon, zirconium, and Hastelloy inserts with volume of 2.5-4 ml were custom produced on a lathe from solid rods of stock materials. Polyethylene inserts were purchased from Niagara Plastic Co. of Erie, PA for a cost of 1.5 cents apiece. These plastic inserts are actually sold commercially as the cups that are pressed into the $3 / 8$ inch pipe unions to protect threads during storage.

Inserts were tested under simulated DWPF conditions by taking melter feed samples in a sampling loop identical to those in the DWPF. The general scheme used in the experiments was simply to alternate between filling inserts and full vials. The melter feed was then quantitatively transferred from the inserts and vials into platinum crucibles and vitrified by heating at $1100^{\circ} \mathrm{C}$ for 1.5 hours. The glass was crushed in a mixer mill and dissolved with a sodium peroxide fusion technique followed by addition of water and concentrated hydrochloric acid. In some experiments a microwave-assisted acid dissolution was also used to dissolve glass.

A room temperature dissolution method was applied to slurries taken in inserts and, in one case, to crushed glass samples. The general scheme for an insert with $1.5-2 \mathrm{ml}$ capacity follows:

1. Pre-weigh a wide-mouth $250 \mathrm{ml}$ plastic bottle and cap and with an insert inside the bottle.

2. Remove the insert, place the insert inside the insert holder and take the sample via the sampling loop. Decant the sample into the plastic bottle and immediately re-weigh from which the sample weight is obtained by difference.

3. Add a mixture of $20 \mathrm{ml}$ concentrated $\mathrm{HF}$ and $20 \mathrm{ml}$ concentrated $\mathrm{HCl}$. Immediately cap the bottle.

4. Mix for 30 minutes.

5. Dilute as appropriate for ICP-AES analysis. We usually transfer a1-3 $\mathrm{ml}$ portion of the solution to a $250 \mathrm{ml}$ plastic volumetric flask, weigh the amount of solution transferred, add, $10 \mathrm{ml}$ of concentrated $\mathrm{HCl}$ to keep the acid concentration above $1 \%$, dilute to the mark, and then analyze this solution by ICP-AES. 


\section{Statistical Analyses}

The elemental analysis results were placed into Excel spreadsheets and the built-in regression and statistical functions used to analyze the data. The statistical analyses were performed at the $95 \%$ confidence level. Typically, the results of two experiments were compared. First, an F-test was used to determine if the variances of the two experiments differed at the $95 \%$ confidence level, next, the means were compared by a t-test.

\section{Results and Discussion}

\section{Effect of Insert on Sampling}

The focus of the insert testing program was to determine if the insert placed in the neck of the sample vial produced the same sample as filling the entire vial. The insert does not mechanically affect sampling, since slurries flow into and out of the insert just as they do the full vial. However, there was some concern that subtle errors introduced as the sampling valve closes to take the sample would be more pronounced when the sample size was reduced from $14 \mathrm{ml}$ to $1.5-3 \mathrm{ml}$.

Three series of sampling loop experiments were performed to compare samples taken in inserts versus samples in full vial. The emphasis in each sampling loop experiment was to measure the $\mathrm{Fe} / \mathrm{Li}$ ratio of melter feed samples taken in inserts versus samples in full vials. The $\mathrm{Fe} / \mathrm{Li}$ ratio is a sensitive indicator of sample differences because the Fe come exclusively from the sludge and $\mathrm{Li}$ comes exclusively from the frit.

The high precision and excellent agreement of the $\mathrm{Fe} / \mathrm{Li}$ ratio of samples taken in inserts and full vials indicate that the inserts do not introduce a significant bias to sampling. In fact, insert sampling should improve analytical reliability by providing samples that can be analyzed intact with almost no chance of corrupting the sample during remote handling in shielded cells. In contrast, vitrification of samples taken in full vials requires considerable operator skill to remove slurry from vials and then go through the tedious steps of drying, vitrification, and crushing without corrupting the samples. Slurry samples could also be obtained by subsampling the full vial. However, subsampling is susceptible to errors because of experimental difficulties of removing a small volume of the heterogeneous sludge from the vial. Since the elemental analysis of the melter feed samples indicates the relative amounts of sludge and frit, it is crucial to not corrupt the sample during the analysis.

\section{Sampling Loop Experiment \#1}

In this experiment, dual goals were to measure the Fe/Li ratio of samples in inserts and full vials and to determine if the time the sample flowed through the inserts and vials had any effect on the Fe/Li ratio. Flow times of 1,2, 5 and 10 seconds were used. Triplicate 
samples were taken at each flow time. After filling the inserts and vials, he melter feed was quantitatively transferred to platinum crucibles and vitrified at $1100^{\circ} \mathrm{C}$ for 1.5 hours. A portion of the glass was crushed and dissolved with sodium peroxide fusion.

The results of Sampling Loop Experiment \#1 are summarized in Table 1. There was no statistical difference at the $95 \%$ confidence level in the precision of the insert samples versus full vials at any of the flow times. There was no statistical difference in the means at the flow times of 1,5 , and 10 seconds, but there was a difference in the means at 2 seconds. The effect of the flow time was minimal, and no clear pattern emerged from the $\mathrm{Fe} / \mathrm{Li}$ ratios as a function of flow time.

\section{Sampling Loop Experiment \# 2}

In this experiment, a set of 3 "Dip" samples were taken from the melter feed tank with a Coliwasa sampler. A set of 3 "Overflow" samples were taken from the overflow spout of the tank sampling system. Using the tank sampling system valve, a total of 7 full vial samples were taken and 14 insert samples (volume about $3 \mathrm{ml}$ ) were taken. Except for 7 of the insert samples, all samples were dried and vitrified. Glass samples were completely crushed in a mixer mill and then dissolved with the sodium peroxide fusion method. The 7 inserts samples that were not vitrified were dissolved with a mixture of $20 \mathrm{ml}$ concentrated $\mathrm{HF}$ and $20 \mathrm{ml}$ concentrated $\mathrm{HCl}$. All solutions were then analyzed by ICP-AES techniques.

The Fe/Li ratio results of Sampling Loop Experiment \# 2 are summarized in Table 2. There was excellent agreement between the insert and full vial samples. There was a slight but statistically significant difference in the means when both sets of samples were vitrified (the t-test statistical analysis gave a t statistical value of 2.27 , versus a $t$-Critical value of 2.18 , so the insert versus vial t-test barely failed). However, the statistical tests indicated no difference in insert versus vial when the insert samples were dissolved as slurries. Since there is no apparent technical reason for insert and vial samples to agree for the slurry samples, the difference in insert and full vial is insignificant from the practical standpoint.

The statistical treatment also found no difference in either the insert or peanut vial samples wit the Dip and Overflow samples. These samples showed a mean Fe/Li ratio about $6 \%$ lower than the full vial samples and $4 \%$ lower than the insert samples. But poorer precision of Dip and Overflow samples made this difference in the means statistically insignificant. The poorer precision of Dip and Overflow samples may have resulted from greater experimental difficulties associated with vitrifying about $150 \mathrm{ml}$ of melter feed that was collected in taking these samples. Dip and Overflow samples are usually considered the reference samples in this sampling system, since these samples are free of subtle biases that may be introduced by the closing the valve to take sample in the tank sampling loop.

The close agreement in the insert and vial samples is apparent by comparing insert versus vial samples in the total elemental analysis of the sodium peroxide fusion 
dissolution and microwave-assisted acid dissolution in Tables 3 and 4, respectively. The slightly higher amount of frit in the insert samples, first indicated by the lower Fe/Li ratio (4.98 versus 4.88 ), is borne out by total elemental analysis. The $\mathrm{Ca}$ analysis of the vitrified insert samples from the sodium peroxide fusion is the only major discrepancy in the data sets. This discrepancy is due to the sodium peroxide fusion workup, since the microwaveassisted acid dissolutions of the same glass samples agree well for $\mathrm{Ca}$. The root source of the error in the sodium peroxide fusion dissolutions has not yet been found.

The most compelling results in this paper in terms of increasing the efficiency of the DWPF laboratory is summarized in Table 5. The results show that a simple room temperature dissolution of slurry samples produces elemental analyses that correlate very well with the elemental analyses of glass samples produced after vitrifying melter feed and then dissolving the glass with sodium peroxide and microwave-assisted acid methods. The glass/slurry ratio for most elements is in the range of 2.9-3.1. This glass/slurry ratio is what would be expected for a melter feed slurry with a calcined wt\% solids content of 33$34 \%$, just as we measured on the melter feed by heating to dryness at $600^{\circ} \mathrm{C}$.

The results indicate that the composition of glass resulting from vitrifying melter feed of sludge-frit mixtures can be reliably arrived at by coupling the elemental analysis of the melter feed with calcined weight \% solids measurements. A breakthrough in analytical speed is achieved with this approach. The elemental analysis and weight \% calcined solids measurements can be obtained in 8 hours or less compared with the 40 hours required when the samples are vitrified.

\section{Sampling Loop Experiment \# 3}

The primary purpose of this experiment was to test polyethylene pipe thread protectors as inserts. These inserts have a huge cost advantage over inserts made at SRTC because they are commercially available for only 1.5 cents apiece. The $1.5 \mathrm{ml}$ volume if the inserts is also a convenient size for elemental analyses, titrations, and weight $\%$ solids measurements at $115^{\circ} \mathrm{C}$.

This experiment consisted of taking samples in polyethylene inserts and full vials via the tank sampling system, and Overflow samples from the tank sampling system. Half the insert samples were placed in the SRTC Shielded Cell Facility for remote dissolutions, and half were dissolved in the laboratory. Vial samples were vitrified and analyzed as glass samples.

The results of Sampling Loop Experiment \#3 are summarized in Table 6. There was no statistically significant difference in the precision or mean of samples taken in inserts versus peanut vials. There was no difference in the full vial and Overflow sample, but there was a slight but statistically significant difference in the insert and Overflow sample.

Half the insert samples were worked up remotely. Fe/Li ratio of these samples were very close to those measured in the conventional laboratory, indicating that the remote 
work-ups can be done without corrupting the sample. The other important result of the incell experiment is that it is clear that the inserts can be easily handled remotely.

\section{Summary of Advantages of Using Sample Vial Inserts}

\section{- Better Accuracy and Precision}

A significant source of analytical error for DWPF samples comes from subsampling the heterogeneous slurries from vials. SRTC and the DWPF have spent at least a decade working on ways to ensure that the most representative sample possible is transferred from the process tanks to the sample vial. But additional analytical errors frequently occur when the vial is subsampled. The insert approach eliminates the analytical error subsampling errors by providing an amount of sample convenient for analysis.

\section{- Convenience}

The use of inserts to take samples is not only fundamentally sound, but also a highly convenient way to handle radioactive slurry samples in a shielded cell. The insert provides a packet of sample that is much easier for a shielded cell operator to deal with than any other approach (short of having the tank sampling system deliver 1-3 ml of sample directly into the analysis vessel, which would be extremely difficult to engineer in a shielded cell environment because of the high flow rates of the samples). The shielded cell operator never has to worry about mixing slurries, taking subsamples, or rinsing samples from vials with this approach. Analyzing slurries also eliminates the tedious operation of weighing out powdered samples remotely.

- Speed

The reduction of analytical time comes through analyzing slurries. The insert approach indirectly speeds up analyses by providing a packet of sample that can be analyzed with a greatly reduced chance of corrupting the sample. Since the entire contents of the insert are used, the time-consuming steps of drying and vitrifying samples to ensure homogeneity are eliminated.

- Quicker Analyses Permit More Replicates

The uncertainty in analytical measurements is usually reduced by increasing the number of replicates. The insert approach, especially when coupled with a simplified dissolution procedure, makes it possible to perform more replicates by reducing the sample preparation time. In other words, the analytical time would be spent actually measuring the composition of tank samples rather than converting them to solids. Analyzing slurry samples provides this advantage whether they are taken in insert or a full vial, but the insert provides a sample that can be analyzed with confidence.

- Waste Minimization

Dealing with radioactive waste will be one of the biggest problems faced by the DWPF Laboratory. The insert approach significantly reduces the amount of waste. The 
sample size is much smaller, and since the entire sample is analyzed, there simply will be less waste. Contrast this approach to the many grams of radioactive waste that will have to be disposed of when the melter feed is vitrified. The insert approach also eliminates glass vials as an important source of radioactive waste that must be periodically removed from the shielded cells. Therefore, the insert approach minimizes waste by reducing the total amount of sample introduced into the cells and then obviates the need to dispose of solid samples and vials.

- ALARA Considerations

The advantages that minimize waste also hold ALARA (As Low As Reasonably Achievable) principles to minimize personnel exposure to radiation. The decreased sample size, shorter analysis time, and simplicity of the proposed methods act in concert to reduce radiation exposure. 


\section{Reference}

1. C.J. Coleman, M.J. Whitaker, W.G. Ramsey, and W.A. Spencer, Slurry Sampling and Dissolutions For Elemental Analysis of the Melter Feed in the Defense Waste

Processing Facility", Oak Ridge National Laboratory-DOE Conference on Analytical Chemistry in Energy Technology, Gatlinburg, Tennessee, Oct.11-13, 1994. 


\section{Table 1}

\section{Sampling Loop Experiment \# 1 \\ Comparison of Fe/Li Ratio of Teflon Insert and Vial Samples as a Function of Sample Flow Times}

Flow Time

2 seconds

5 seconds

10 seconds

30 seconds second

Fe/Li Ratio

\begin{tabular}{|c|c|}
\hline Inserts $\mathrm{n}=\mathbf{3}$ & Vials $n=3$ \\
\hline $3.66(3.5 \%$ RSD $)$ & $3.78(6.8 \%$ RSD $)$ \\
\hline 4.04 (6.7 \% RSD) & 3.71 (3.8 \% RSD) \\
\hline $3.87(5.2 \%$ RSD $)$ & $3.79(2.9 \%$ RSD $)$ \\
\hline 3.94 (4.9 \% RSD) & 3.97 (7.5 \% RSD) \\
\hline $3.84(6.5 \%$ RSD $)$ & no samples taken \\
\hline
\end{tabular}

\section{$\underline{\text { Statistical Tests }}$}

Are Insert and Vial Samples

the Same at $95 \%$ Confidence Level ?

Flow Time

1 second

2 seconds

5 seconds

10 seconds

\begin{tabular}{cl} 
Precision & Mean \\
\cline { 1 - 1 } & Yes \\
Yes & No \\
Yes & Yes \\
Yes & Yes
\end{tabular}

Precision data reflect total analytical precision of the experiment, including tank sampling. 


\section{Table 2 \\ Sampling Loop Experiment \# 2 \\ Comparison of $\mathrm{Fe} / \mathrm{Li}$ Ratio Measurements of Teflon Insert and Vial Samples}

Vial (vitrified sample)

Sodium Peroxide Fusion Diss.

Teflon Insert (vitrified sample)

Sodium Peroxide Fusion Diss.

Teflon Insert (slurry sample)

Room Temp. Acid Diss.

Dip Samples (vitrified samples)

Sodium Peroxide Fusion Diss.

Overflow Samples (vitrified samples)

Sodium Peroxide Fusion Diss.
Fe/Li Ratios

$4.98 \quad(2.0 \% \mathrm{RSD})$

$\mathrm{n}=7$

4.88 (1.4 \% RSD)

$\mathrm{n}=7$

$4.93 \quad(2.2 \%$ RSD)

$\mathrm{n}=7$

$4.70 \quad$ (3.6 \% RSD)

$\mathbf{n}=\mathbf{3}$

$4.71 \quad(4.3 \%$ RSD)

$\mathrm{n}=\mathbf{3}$

\section{$\underline{\text { Statistical Tests }}$}

\section{Comparsion}

vial (glass) vs. insert (glass)

vial (glass) vs. insert (slurry)

insert (glass) vs. insert (slurry)
Same at $95 \%$ confidence level ?

\section{Precision Mean}

yes

no

yes

yes

yes

yes

Precision data reflect total analytical precision of the experiment, including tank sampling. 


\section{Table 3}

\section{Sampling Loop Experiment \# 2 \\ Comparison of Elemental Analyses of Vitrified Insert and Vitrified Vial Samples}

\begin{tabular}{|c|c|c|c|c|c|c|}
\hline \multirow[b]{2}{*}{ Element } & \multicolumn{5}{|c|}{ Sodium Peroxide Fusion Dissolution } & \\
\hline & \multicolumn{3}{|c|}{$\frac{\text { Insert Samples }}{n=7}$} & \multicolumn{3}{|c|}{$\underset{n=7}{\text { Yial Samples }}$} \\
\hline $\mathrm{Al}$ & 1.70 & 0.018 & 1.09 & 1.70 & 0.028 & 1.67 \\
\hline B & 2.24 & 0.041 & 1.86 & 2.26 & 0.032 & 1.43 \\
\hline $\mathbf{B a}$ & 0.099 & 0.002 & 1.97 & 0.102 & 0.003 & 3.34 \\
\hline $\mathbf{C a}$ & 0.586 & 0.087 & 14.9 & 0.711 & 0.016 & 2.31 \\
\hline $\mathbf{C r}$ & 0.980 & 0.002 & 1.73 & 0.102 & 0.002 & 1.44 \\
\hline $\mathrm{Cu}$ & 0.361 & 0.007 & 1.90 & 0.378 & 0.005 & 1.30 \\
\hline $\mathbf{F e}$ & 9.70 & 0.086 & 0.89 & 9.85 & 0.160 & 1.62 \\
\hline $\mathbf{L i}$ & 1.99 & 0.017 & 0.85 & 1.98 & 0.030 & 1.50 \\
\hline $\mathbf{M g}$ & 0.850 & 0.020 & 2.3 & 0.856 & 0.015 & 1.70 \\
\hline Mn & 1.91 & 0.030 & 1.59 & 1.95 & 0.016 & 0.83 \\
\hline $\mathrm{Na}$ & footnote a. & & & footnote & & \\
\hline $\mathbf{N i}$ & 0.886 & 0.013 & 1.49 & 0.920 & 0.018 & 1.96 \\
\hline $\mathbf{S i}$ & 25.4 & $\mathbf{0 . 3 2 0}$ & 1.28 & 24.9 & 0.34 & 1.36 \\
\hline $\mathbf{S r}$ & 0.013 & 0.002 & $16.0 \%$ & 0.014 & 0.001 & 7.14 \\
\hline $\mathbf{T i}$ & 0.196 & 0.002 & 1.02 & 0.197 & 0.003 & 1.62 \\
\hline $\mathbf{Z n}$ & 0.104 & 0.005 & 5.7 & 0.103 & 0.001 & 1.36 \\
\hline $\mathbf{Z r}$ & footnote a. & & & footnote & & \\
\hline
\end{tabular}

a. Na and $\mathrm{Zr}$ are not measured from this dissolution because $\mathrm{Na}$ is introduced from sodium peroxide and $\mathrm{Zr}$ is introduced from the $\mathrm{Zr}$ crucible used in the fusion. 


\section{Table 4 \\ Sampling Loop Experiment \# 2 \\ Comparison of Elemental Analyses of \\ Vitrified Insert and Vial Samples}

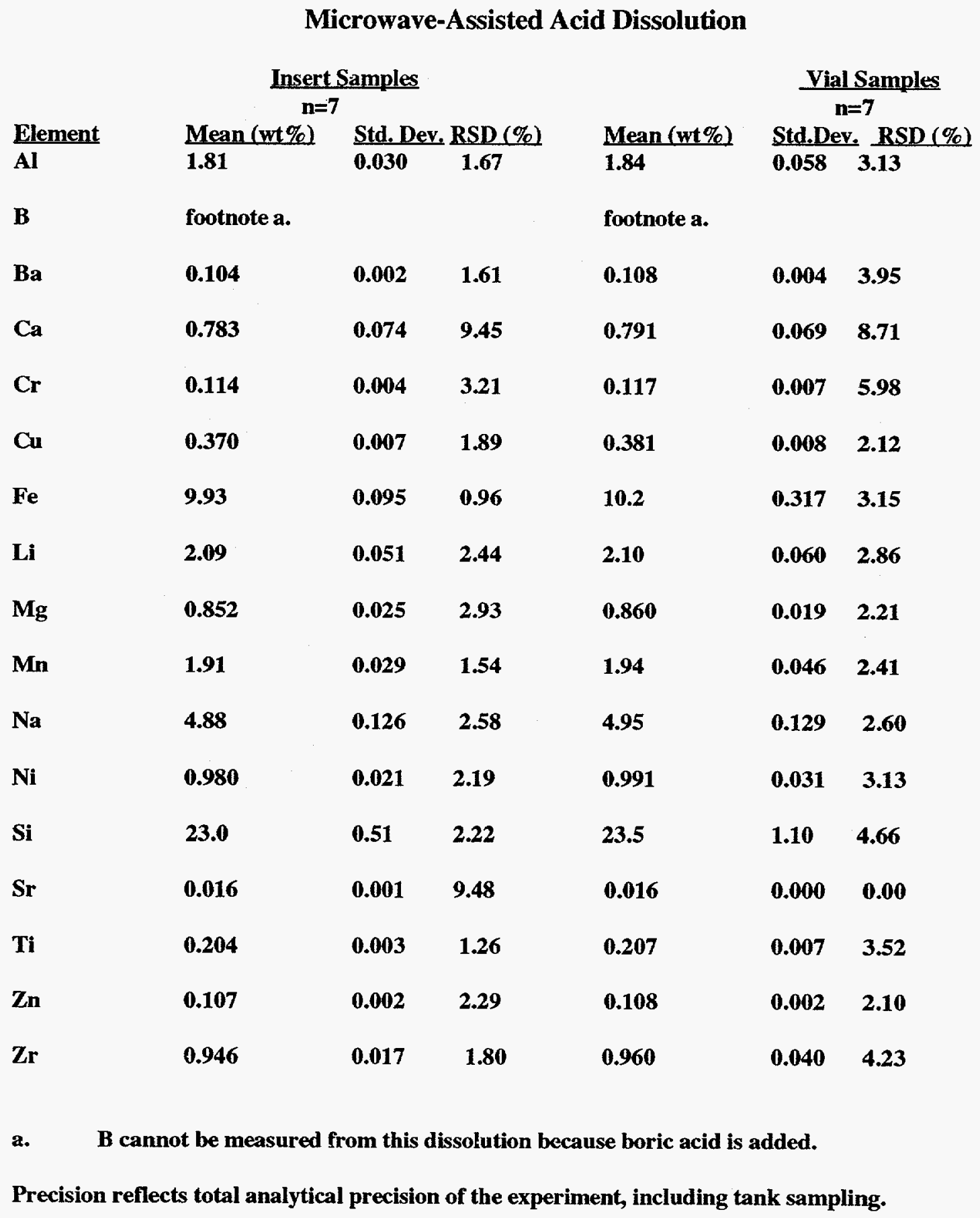




\section{Table 5 \\ Sampling Loop Experiment \# 2 \\ Elemental Analyses of Insert Slurry Samples and Ratio of Glass/Slurry Elemental Analyses}

\begin{tabular}{|c|c|c|c|c|c|}
\hline \multirow[b]{2}{*}{ Element } & \multicolumn{3}{|c|}{ Insert Slurry Samples } & \multirow[b]{2}{*}{$\begin{array}{c}\text { Glass/Slurry } \\
\text { Ratio }^{\mathbf{a}}\end{array}$} & \multirow[b]{2}{*}{$\begin{array}{c}\text { Glass/Slurry } \\
\text { Ratio b }^{\text {b }}\end{array}$} \\
\hline & $\operatorname{Mean}(w t \%)$ & $\begin{array}{l}n=7 \\
\text { Std. Dev. }\end{array}$ & RSD. (\%) & & \\
\hline Al & 0.585 & 0.011 & 1.95 & 2.91 & 3.09 \\
\hline $\mathbf{B}$ & 0.785 & 0.009 & 1.11 & 2.85 & N/A \\
\hline $\mathbf{B a}$ & 0.034 & 0.0005 & 1.44 & 2.92 & 3.06 \\
\hline $\mathbf{C a}$ & 0.289 & 0.003 & 1.13 & 2.03 & 2.71 \\
\hline $\mathrm{Cr}$ & 0.029 & $\mathbf{0 . 0 0 3}$ & 10.8 & 3.38 & 3.93 \\
\hline Cu & 0.127 & 0.002 & 1.63 & 2.84 & 2.91 \\
\hline $\mathbf{F e}$ & 3.32 & 0.05 & 1.50 & 2.92 & 2.99 \\
\hline $\mathbf{L i}$ & 0.675 & 0.011 & 1.63 & 2.95 & 3.10 \\
\hline $\mathbf{M g}$ & 0.281 & 0.004 & 1.61 & 3.02 & 3.02 \\
\hline $\mathbf{M n}$ & 0.641 & 0.010 & 1.57 & 2.98 & 2.98 \\
\hline $\mathbf{N a}$ & 1.62 & 0.018 & 1.11 & $\mathbf{N} / \mathbf{A}$ & 3.01 \\
\hline $\mathbf{N i}$ & $\mathbf{0 . 3 3 3}$ & 0.006 & 1.95 & 2.68 & 2.94 \\
\hline $\mathbf{S i}$ & 8.15 & 0.14 & 1.77 & 3.12 & 2.82 \\
\hline Sr & 0.005 & $\mathbf{0 . 0 0 0}$ & $\mathbf{0 . 0 0}$ & 2.60 & 3.20 \\
\hline $\mathbf{T i}$ & 0.067 & 0.001 & 2.18 & 2.98 & 3.04 \\
\hline $\mathbf{Z n}$ & 0.035 & 0.001 & 2.72 & 2.97 & 3.06 \\
\hline $\mathbf{Z r}$ & 0.32 & 0.015 & 4.69 & N/A & 2.97 \\
\hline
\end{tabular}

a. Sodium peroxide fusion dissolution used for glass elemental analyses.

b. Microwave-assisted acid dissolution used for glass elemental analyses

Precision reflects total analytical precision of the experiment, including tank sampling. 


\section{Table 6 \\ Results of Sampling Loop Experiment \# 3 \\ Comparison of $\mathrm{Fe} / \mathrm{Li}$ Ratio Measurements of Polyethylene Insert and Vial Samples}

Vial (vitrified sample) Room Temperature Acid Dissolution
Fe/Li Ratios 4.37 (1.2\% RSD) $\mathrm{n}=6$

Polyethylene Insert (slurry sample) $4.31 \quad$ (0.8 \% RSD) Room Temp. Acid Diss. $\quad n=5$

Polyethylene Insert (slurry sample) $4.37 \quad(2.0 \%$ RSD) Room Temp. Acid Diss. $\mathrm{n}=5$ (Remote Shielded Cell Work-ups)

\section{Statistical Tests}

Same at $95 \%$ confidence level ?

Comparsion

vial (glass) vs. insert (slurry)

vial (glass) vs. insert (slurry)

(remote shielded cell work-ups on inserts)

\section{Precision Mean \\ yes \\ yes}

yes

yes

Overflow (glass) vs. insert (slurry) yes no

Overflow (glass) vs. vial (glass)

yes

yes

Overflow (glass) vs insert (slurry)

(remote shielded cell workup on inserts) yes yes 